\title{
Newborn skin care strategies in neonatal unit
}

\section{Estratégias de cuidado com a pele do recém-nascido em unidade de internação neonatal}

\section{Estrategias de cuidado de la piel del recién nacido en unidad neonatal}

\author{
Bruna Schiphorst Delgado ${ }^{1}$, Roberta Costa ${ }^{1}$, Stéfany Nayara Petry Dal Vesco', \\ Flávia Aguiar Santos ${ }^{1}$, Simone Vidal Santos ${ }^{1,2^{*}}$
}

\section{ORCID IDS}

Delgado BS (iD https://orcid.org/0000-0002-8412-7118

Costa R (D) https://orcid.org/0000-0001-6816-2047

Vesco SNP (iD https://orcid.org/0000-0001-9713-247X

Santos FA (iD) https://orcid.org/0000-0002-9729-0299

Santos SV (iD https://orcid.org/0000-0002-5086-6326

\section{HOW TO CITE}

Delgado BS, Costa R, Vesco SNP, Santos FA, Santos SV. Newborn skin care strategies in neonatal unit. ESTIMA, Braz. J. Enterostomal Ther., 16: e1319. https://doi.org/10.30886/estima.v16.745_IN

\begin{abstract}
Objective: To identify skin care strategies for newborns (NB) used in reference centers of the Kangaroo-Mother Care Method (KMC) in Brazil. Methods: Descriptive exploratory study, using a qualitative approach, performed with 13 nurses working in the different reference centers of the KMC in Brazil. Data were collected through an online form. Analysis was performed descriptively, comparing the different studies realities. Results: Four categories were described regarding skin care of NB through the experience of the nurses: strategies adopted by the team regarding skin care of NBs; dealing with the health team regarding bath and dipper disposal; care regarding fixation of devices in NBs, and strategies adopted by the NB team under phototherapy. Conclusion: The nurses presented capacity, and they were highly trained to act in their areas of experience and knowledge. The answers indicated that there is a great concern in avoiding the usage of materials and devices that could cause harm to NB skin.
\end{abstract}

KEYWORDS: Infant, Newborn; Neonatal Intensive Care Units; Skin; Kangaroo-Mother Care Method; Neonatal Nursing. Stomatherapy.

1 Universidade Federal de Santa Catarina - Departamento de Enfermagem - Florianópolis/SC - Brazil.

¿Universidade Federal de Santa Catarina - Hospital Universitário Professor Polydoro Ernani de São Thiago - Florianópolis/SC - Brazil.

Corresponding author: simonevidal75@gmail.com

Received: 4 Apr 2019 | Accepted: 10 Jul 2019 


\section{RESUMO}

Objetivo: Identificar as estratégias de cuidado com a pele dos recém-nascidos (RNs) utilizadas nos centros de referência do Método Canguru (MC) do Brasil. Métodos: Estudo exploratório descritivo, de abordagem qualitativa, realizado com 13 enfermeiras atuantes nos diferentes centros de referência do MC no Brasil. Os dados foram coletados por meio de um formulário online. A análise foi feita de forma descritiva, comparando-se as diferentes realidades. Resultados: Elaboraram-se quatro categorias para o cuidado da pele do RN advindas da experiência dos participantes: estratégias adotadas pela equipe relacionadas aos cuidados com a pele do RN; manejo da equipe de saúde em relação ao banho e troca de fralda; cuidados com a fixação de dispositivos em RNs; e estratégias adotadas pela equipe no RN sob fototerapia. Conclusão: As enfermeiras mostraram-se capacitadas e aptas a atuar em seus campos de experiência e vivência. As respostas indicaram que existe preocupação em evitar a utilização de utensílios e materiais nocivos à pele do RN.

DESCRITORES: Recém-nascido; Unidades de terapia intensiva neonatal; Pele; Método Canguru; Enfermagem neonatal; Estomaterapia.

\section{RESUMEN}

Objetivo: identificar las estrategias de cuidado de la piel del recién nacido (RN) utilizadas en los centros de referencia del Método Canguro (MC) en Brasil. Métodos: Estudio exploratorio descriptivo con enfoque cualitativo, realizado con 13 enfermeras que trabajan en los diferentes centros de referencia de MC en Brasil. Los datos fueron recolectados a través de un formulario online. A análise foi feita de forma descritiva, comparando-se as diferentes realidades. Resultados: se elaboraron cuatro categorías para el cuidado de la piel del RN a partir de la experiencia de los participantes: estrategias adoptadas por el equipo relacionadas con el cuidado de la piel del RN; gestión del equipo de salud en relación con el baño y el cambio de pañales; cuidado con la fijación de dispositivos en RN; y estrategias adoptadas por el equipo en el recién nacido bajo fototerapia. Conclusión: Las enfermeras estaban calificadas y podían trabajar en sus campos de experiencia. As respostas indicaram que existe preocupação em evitar a utilização de utensílios e materiais nocivos à pele do RN. Las respuestas indicaron que existe la preocupación de evitar el uso de utensilios y materiales dañinos para la piel del RN.

DESCRIPTORES: Recién nacido; Unidades de cuidados intensivos neonatales; Piel; Método canguro; Enfermería Neonatal; Estomaterapia.

\section{INTRODUCTION}

It is estimated that, annually, over 20 million underweight, premature babies are born in the world, being one-third of these dead before completing one year of life1. Over $60 \%$ of premature births happen in underdeveloped countries, and Brazil is among the 10 countries with higher premature birth index, as well as the USA, India, and Nigeria, being this a global issue ${ }^{2}$. In 2015, 303 thousand women died of pregnancy-related causes, 2.7 million babies died over the first 28 days of life, and 2.6 babies were stillbirth ${ }^{3}$.

Due to the gravity of the issue, the World Health Organization (WHO) idealize a world in which all women and their newborn (NB) can receive quality care in all steps of the pregnancy, from birth to postpartum period. Prenatal care is composed of a strategy platform regarding health promotion, screening, diagnosis, and prevention of illness. The quality of the services during pregnancy and birth may avoid many of the occurring deaths ${ }^{1,3}$.

In order to collaborate to the quality of the care and diminish mortality rates, the Brazilian Unique Health
System (SUS) establishes a standard humanized attention regulation not only to the premature newborn (PNB) but to all the family and makes the family co-participant regarding care to go through this process confidently and soothingly ${ }^{1,3}$.

Advances in medicine and technology have allowed the vast majority of PNB to develop and grow healthy. On the other hand, these babies who are born prematurely are considered fragile, vulnerable, and need special care to survive. Many actions have been stimulated in order to enhance the attending pattern to this population and, among these, in Brazil, the Humanized Attention to premature and underweight newborns - KangarooMother Care Method (KMC), is highlighted ${ }^{1}$.

Initially, the KMC was idealized by the Maternal and Child Institute, in Bogotá, Colombia, is the act of placing the NB in intimate contact with the mother's skin an alternative to reduce costs of assistance, enhance care to PNM and promote the new bond between mother and baby ${ }^{4}$. In Brazil, the KMC has been inserted in some units since the 1990s and, in the year 2000, the Health Minister launched the 693 from July 5th. Law, updated in 2007 by the 1.683 Law, which established 
the necessary parameters to implant the method in the units and also to habilitate the multi-professional team ${ }^{5}$.

The Health Minister protocol is divided into three steps and begins with prenatal care when high-risk pregnancy is diagnosed. The first step occurs in Neonatal Intensive Care Unit (UTIN) or the Conventional Intermediate Care Unit (UCINCo), when the baby is born and is still unstable, depending on the care of the team. In this step, parents must be encouraged by the team to participate in the baby's care and may initiate their participation during the bathing time and diaper exchange ${ }^{1}$.

The second step depends on the availability of the mother to remain with the NB in the hospital and, in most of the time, in the kangaroo position. This step occurs in the Intermediate Neonatal Kangaroo Unit, which is a wing of the UTIN, in which the mother is the principal care provider of the $\mathrm{NB}^{1}$.

The third step occurs after the baby being discharged from the hospital, which initiates when NB gains at least $1.600 \mathrm{~g}$ of weight, being clinically stable and presenting progressing weight gaining.

The mother needs to be motivated to take the NB home and make the commitment to perform the kangaroo position during the most time as possible. The consultation will be performed in the office by the multi-professional team at least once a week. The NB is discharged from the third step when achieves 2.500 grams of weight ${ }^{1}$.

National and state reference centers were created, with the formation of tutors, to provide the implantation of the method in several hospitals in the country. Nowadays, in Brazil, there are five national reference centers and 27 state references, being these units considered places to develop good habits with the $\mathrm{NB}^{4}$. Among the right habits, the NB skin care is highlighted.

The skin is the largest organ of the human body, composed by epidermis and dermis, two layers that find themselves firmly adhered and supported by the subcutaneous tissue. The epidermis is composed by four layers, being the most external one the corneous extract, which performs the function of barrier against the loss of fluids through the skin, as well as invasion of agents from the outside, helping in the protection of the skin and the organism itself. The dermis is composed of collagen fibers and elastin, which guarantees the support, elasticity, and skin resistance ${ }^{6}$.
Skin care of NB should be present since birth and demand constant worry by the professionals that work in neonatal unit ${ }^{7,8}$. The skin of $\mathrm{NB}$, especially premature NB have specific anatomic and physiological characteristics, due to its immaturity, being thinner, more delicate, sensible, which makes this population more likely to the development of lesions and infection ${ }^{6,9}$. For this reason, planning the nursing assistance and implementing actions that aim evaluation and skin care is essential regarding the quality of the assistance and the success of the treatment in neonathology ${ }^{10}$.

Reference centers have become places of good habits regarding assistance. In this scenario, skin care of NB needs double attention from the nurses and its staff. It is estimated that neonatal units constitute fertile fields in which new technologies may appear, helping the skin care of NB.

Within this context, the present study has elaborated the following question: which strategies are used regarding $\mathrm{NB}$ skin care in reference centers of the KMC in Brazil? The study had the purpose of identifying NB skin care strategies in reference centers of the KMC in Brazil.

\section{METHOD}

This is a descriptive exploratory study, with a qualitative approach, performed through a macro project untitled "NB and their families care technologies in KMC: contributions of the nurses from UTIN" developed by the Federal University of Santa Catarina. This part of the study aimed to identify the strategies regarding skin care of NB used by the nurses in $\mathrm{KMC}$ reference centers in Brazil.

All reference centers were invited to participate in the study; however, 27 presented a consent letter. The contact occurred through the coordinator of the centers. A total of 55 nurses were invited, through a mailed invitation latter. Of these, 27 did not answer the e-mail, 15 accepted to participate but did not fill the form, and 13 nurses from different reference centers effectively participated in the study. The inclusion criteria were: has been acting for at least six months in the unit and being a tutor or consultant of KMC. The exclusion criteria were the absence from work due to illness or maternity leave. 
The study was performed in neonatal units from 13 reference centers of $\mathrm{KMC}$ in Brazil, located in the states of Santa Catarina, São Paulo, Rio de Janeiro, Paraná, Ceará, Maranhão, Pernambuco, Piauí, Amapá, Pará, Espírito Santo, and Tocantins. Data were obtained using online forms by Google Docs ${ }^{\circledR}$, and those forms were answered from June do December 2016.

The form had 94 questions, which varied from multiple choices to open questions, which allowed the nurses to talk about the topic. Three sections were part of the form: participant characterization; data on the institution and questions about care technologies regarding NB assistance. This study focused on questions regarding the third part of the form, facing the NB skin care in UTIN, UCINCo, and UCINCa.

Data analysis was performed through a grouping of content similarities, which allowed identifying the strategies used by nurses in NB skin care in several aspects of the assistance.

All ethical precepts were followed according to Resolution no 466/2012 from National Health Council 11, and the Ethics Committee approved the research from Santa Catarina Federal University (CAAE 44889615.6.3003.5328). All participants signed the Informed Consent Form.

\section{RESULTS}

A total of 13 nurses participated in the study, being nurses that worked in the KMC Reference Centers in Brazil, all women, with age varying from 20 to 60 years and time of graduation between 11 and 20 years. Among these, nine were tutors, and four were consultants of KMC in Brazil.

According to the answers given in the forms, four categories were elaborated, regarding NB skin care, related to the experience of the nurses from the $13 \mathrm{KMC}$ reference centers in Brazil, which were: Strategies adopted by the nursing team related to NB skin care; Bathing and diaper exchange; Care with device fixation in NB; and Strategies adopted with NB under phototherapy.

\section{Strategies adopted by the nursing team regarding NB skin care}

Similar actions were verified, and upcoming specific protocols for each unit were also analyzed. The concern regarding not to use adhesive tapes directly to the skin was highlighted, as well as the usage of protection products.

"Avoid the usage of substances, especially abrasive ones, and diminish the usage of adhesive tapes, care when removing adhesive tapes, avoid exposition and unnecessary maneuvers." (E1)

"Moisten newborn incubator for newborn under 1.000 grams, removal of adhesive with moisture." (E4)

"Written routine regarding premature skin care and prevention of skin lesions commission." (E6)

"Protocol of skin lesion, care with oxymeters" (E10)

"Cavilom ${ }^{\circledR}$ barrier; Dersani ${ }^{\circledR}$ age; bath at every 72 hours (extremely underweight babies).” (E11)

"Use of oils. Do not fix adhesive tapes directly to the skin. Use hypoallergenic adhesive tapes. Use of proper antiseptic according to NB weight.” (E12)

"Urea cream, hydrocolloid plaques, change of position, comforting massage." (E13)

It was observed the diversity of conducts; thus, similar interventions were established regarding NB skin care. The nurses described that they avoid the use of adhesive tape, which may be harmful to the skin. Frequently, answers such as the use of oil, creams, and hydrocolloid plaques were given as best adopted conducts. However, there is no recommendation in the literature regarding the use of urea cream in NB, as described by one of the participants in the study.

\section{Bathing time and diaper exchange}

Regarding NB bathing time, it was observed that the protocol and the routine in each unit vary, since they were cited by some participants, as others just mentioned the cleaning of the perineum area. Regarding diaper exchange, it was performed laterally, to avoid complications.

\footnotetext{
"Bathing only when needed, or when the baby presents itself as stable, respecting the signs and tolerance, using
} 
the rolling technique and diaper exchange carefully performed, not to elevate the MMII, always inviting the mother to participate. "(E1)

"A protocol is followed regarding skin, bathing according to weight, and laterally diaper exchanges." (E3)

"According to the Kangaroo-Mother Care Method, ratified by a protocol." (E5)

"Humanized bath, hot tub, and diaper exchange laterally." (E6)

"Baths are not performed on premature NB, only cleaning of the perineum.” (E8)

"According to our skin lesion protocol and following the operational procedures bathing is at every $48 \mathrm{~h}$, using cotton, tepid water and nothing with perfume." (E10)

"Bathing is performed every other day and depending on the gravity of the $\mathrm{NB}$, diaper exchange is at every 3 hours, before dieting or whenever necessary." (E12)

NB bathing appeared as a specific strategy in every unit, not being something unique for all units, since each and every unit has its internal routine regarding the NB's body cleaning. Bathing was also described as a way to implement other care actions, such as nursing and family bonding at this time.

\section{Care with device fixation in NB}

In this item, again, it was noticed the reality of each unit, with different answers showing the availability of some needed material for the practice of nursing in NB care.

"Bandages less aggressive as possible to the skin, plaster minimum as possible.” (E2)

"Minimize the use of adhesive tapes, use of hydrocolloid."(E3)

"Fixation of a gastric tube with TOP, CPAP and Tensoplastâ, removal of adhesives with Dersani." (E4)

"Transparent bandage that allows remaining in position for seven days and it is not irritant to the skin. TOT is fixed with Tensoplastâ, and gastric tubes are fixed with gauze on the zygomatic bone." (E5)

"Abocath and PICC are fixed in transparent film.”(E6)

"Use of micropore and prioritize the smaller size possible when considering adherence on the skin.” (E7)

"Avoid the use of unnecessary fixation, with proper materials for each catheter. Extra-thin hydrocolloid bandage is what we use and elastic bandages to involve the sensors." (E10)

"TOT, CPAP, oxygen catheter, a gastric tube is fixed with plaster, but first we put Duoderme. PICC and Abocath are fixed with sterile film bandage, when it is available in the hospital, being the exchange performed every seven days, as long as it is clean and whole, or with micropore or gauze, being exchanged every 48 hours.” (E12)

Different materials usage was identified regarding the low potential of skin lesion, as well as different strategies at the moment of device fixation. The answers of the participants highlighted that the NB care presents specificities that vary according to the availability of materials and routine in each service.

\section{Strategies adopted with NB under phototherapy}

"Protection of the eyes, exposition of the maximum of area possible under the light. Avoid the usage of substances on the skin. Use of diapers.” (E1)

"Protection goggles, alternate the kangaroo position, temperature under the arm, control of diuresis." (E2)

"Correct posture, rolls, non-nutritional suction (use of pacifiers when needed).”(E3)

"Change of masks every 24 hours and every 3 hours phototherapy is turned off, and the mask is removed for a few minutes.” (E5)

"Use of protective goggles and if possible breastfeeding." (E8) 
"Plastic film protection to reduce the cold temperature [...].” (E9)

"No type of cream on the skin, change of position, temperature control under the arm every 4 hours." (E10)

"Eye protection with tissue goggles (UCINCa) and eye protection with disposable goggles when available (UTIN).” (E11)

“Temperature and diuresis control, use of eye protection."

The vast majority of nurses described concerns regarding NB eyes when phototherapy is performed. They also described actions regarding skin care, such as avoiding the use of topic substances that could be harmful to the NB skin and the need for changing the NB position.

\section{DISCUSSION}

The main strategies adopted by nurses showed that they have the necessary knowledge regarding essential and indispensable care to the prevention of NB skin lesions. One crucial topic pointed by the majority of the participants was the need to avoid the use of adhesives. Skin lesions related to medical adhesives (medical adhesive related skin injury MARSI) occur when the bond between the adhesive and the skin is higher than the cohesion between the skin layers and include mechanical lesion, tension lesion or skin blisters. In the neonatal population, the most common mechanism of MARSI is epidermic pickling ${ }^{12}$.

The use of adhesives for the fixation of devices such as an orotracheal tube (TOT), nasogastric catheters, venipuncture, among others, may cause considerable epidermic loss when considering NB. To avoid those lesions, the skin must be protected using a product that forms a barrier between the skin and the adhesive, such as the hydrocolloid plaque ${ }^{12}$. This fact is proven and used by professional of these reference centers when definite answers emerge regarding the use of hydrocolloid plaque as a way to avoid skin lesions. Adding to this conduct, one must pay careful attention to the removal of fixation, using gauze compresses soaked in saline solution or mineral oil, to prevent lesions during procedure ${ }^{12}$.
Care in neonatal units embraces several techniques and procedures such as the use of antiseptic solutions, invasive procedures, temperature maintenance, positioning of the NB, body hygiene, fixation/removal of adhesive, use of invasive devices and monitors, among other procedures and actions, which predispose NB to the onset of lesions ${ }^{13,14}$.

Studies have shown that the leading causes of these skin lesions are related to the use and device fixation, heat sources, use of drugs intravenously administered, incontinence, and use of chemical products ${ }^{13-15}$.

The use of antiseptics, for instance, is considered a great dilemma regarding NB skin care, since at the same time that the help the prevention of infection, they also may cause lesions. Another point to be considered is the inexistence of a safe and adequate product to use for this specific population. The formulation of such products must be carefully considered, avoiding solutions with alcohol, prioritizing solutions with water and irrigating the area with saline after the disinfection, in order to remove the excess of the antiseptic, avoiding absorption, chemical irritation, and lesion formation 16.

The continuous positive airway pressure (CPAP), which is a non-invasive ventilation system for the upper airways, is considered one of the principal causes of NB lesion. The device consists of the use of tracheas and a nasal mask, adapted to the child's nose. The tracheas are fixed on the head of the NB, bilaterally or in the frontal region, depending on the manufacturer. The mask stays in intimate contact with the nose, upper lip area, and all regions around the nose. The constant pressure of the tracheas may cause pressure lesion. A systematic review showed that babies with less than 30 weeks of gestational age are more susceptible to this type of lesion and showed that the use of barriers, such as hydrocolloid plaque in the areas of CPAP contact to the skin, is a solution ${ }^{17}$.

Regarding bathing, there were divergent answers of the participants in the study. The units have each an established routine and protocols, which are followed by the professionals, in order to maintain the NB homeostasis Bathing is considered a routine procedure that follows a cultural tradition and has the purpose of removal of bacterial colonization. Thus, it alters skin $\mathrm{pH}$ and may compromise skin integrity ${ }^{8}$.

Diaper exchange is also a procedure that demands care, once that diaper dermatitis is lesions that occur due 
to the skin contact with urine and feces, which makes urea to be converted to ammonia, making the $\mathrm{pH}$ of a region more alkaline. It is believed that antibiotics may favor the occurrence of diaper dermatitis since these medications alter the consistency of feces. To prevent its occurrence, diaper exchange should be performed whenever needed, using soft tissue or cotton and water for the cleaning of the perianal area of the NB, since chemical products may cause skin irritation, especially in extremely premature babies 7,18. Another essential care during diaper exchange is the use of products to form a protective barrier over the skin, in order to avoid dermatitis caused by diaper contact to the skin, which is very common and has a prevalence of 7 to $50 \%$ of $\mathrm{NB}^{19}$.

It is fundamental that, besides the knowledge of NB's specific physiological and anatomical particularities, nurses should also identify the risk of upcoming lesions, regarding better quality of assistance and, consequently, making it more humane, reducing complications, hospitalization time, mortality, treatment costs and minimizing the physical and emotional suffering of NB in critical conditions, as well as their families ${ }^{20}$.

In the neonatal unit, procedures such as bathing, hydration with oils, use of antiseptic solutions, fixation of adhesives and prevention of water loss and heat are care actions that should be frequently monitored, as well as procedures that involve an exchange of bandages, catheters insertion, punctures, and change of position, among others. All these procedures are part of the nursing assistances and, if poorly executed, may lead to the appearance of lesions, due to the frequency of such procedures during hospitalization time, which is generally long ${ }^{21}$.

Another procedure that may cause NB skin damage, which the purpose is the treatment of hyperbilirubinemia, through the exposure of the NB to artificial light through devices. It is a high impact non-invasive method, which diminishes the level of plasmatic bilirubin, since exposition to light breaks the bilirubin, enabling its metabolism and excretion ${ }^{22}$. For the phototherapy to be effective, the nursing staff must pay attention to some aspects, such as body surface exposed to light, proper distance from the light source, irradiance from the phototherapy device, eye protection, vital signs observation, water balance and avoiding the use of skin substances on the $\mathrm{NB}^{23}$.

Eye protection is essential to avoid damage to the retina and, so, the use of eye goggles that do not need adhesive to direct fixation to the skin must be prioritized. Nowadays, there are eye goggles that adjust correctly to the NB's head, through Velcro or elastic and should be used carefully so that they do not get too tight, leading to lesions nor to loosen, leaving the eye unprotected. It is also essential to remove the goggles when turning the light source off, to examine the eyes regarding edema, drainage, and evidence of infection, as well as providing visual stimulation and encouraging the interaction between baby and parents, when appropriate, according to the clinical stage of the child ${ }^{22}$.

The evaluation of the NB skin is a care strategy to avoid lesions and must be performed by the nurse using the NB Skin Condition Scale (ECPRN), which evaluates dryness, erythema, and lesion ${ }^{24}$. The interval of evaluation may vary from six to 24 hours and must be based on the score of the skin condition, as well as risks, treatment such as phototherapy, use of devices, edema, sedative drugs, diarrhea, among other factors that could contribute to the appearance of lesions.

\section{CONCLUSION}

This study demonstrated the importance of a wellprepared nurse, who is aware of the peculiarities involved in newborn care, especially regarding the maintenance of the integrity and skin. This care must be observed, evaluated, and thoroughly executed to prevent damage that could be avoided appropriately.

Facing the obtained results from this present study, it can be stated that the nurses have shown themselves highly capacitated to act in their respective fields of experience and living. There is also the concern in adopting the best care strategies, in order to avoid the usage of materials or harmful products which could compromise the integrity of the NB skin.

Although different reference centers were studies, distributed in several regions in Brazil, the answers of the participants were homogenous regarding skin care strategies, as well as specific routines of each center when it comes to assistance.

This study has contributed to highlighting the theme which is little addressed in the literature, in order to foment discussions regarding the best care practice, fundamental to the quality of the job, protection of the development and safety of the NB population.

Within the limitations of the study, there was low adherence of nurses regarding the devolution of the forms in the reference centers.

It is highly recommended that the nursing staff is always in constant search of updating and empowerment 
to effectively act in NB skin care, fomenting good actions, preventing complications and contributing to NB patient's security and health.

\section{FUNDING}

This research was performed with the financial aid from the National Council for Technological and Scientific Development (CNPq), 14/2013.

\section{AUTHOR'S CONTRIBUTION}

\author{
Conceptualization, Delgado BS; Costa R; Vesco SNP;
} Santos FA and Santos SV; Methodology, Delgado BS and Costa R; Investigation, Delgado BS and Costa R; Writing First version, Delgado BS; Costa R; Vesco SNP; Santos FA and Santos SV; Writing - Revision and Editing, Delgado BS; Costa R; Vesco SNP; Santos FA and Santos SV; Grant acquisition, Costa R; Resources, Delgado BS and Costa R; Supervision, Costa R.

\section{REFERENCES}

1. Ministério da Saúde (BR). Atenção humanizada ao recémnascido de baixo peso: Método Canguru: manual técnico (3a ed.). Brasília: MS; 2017.

2. World Health Organization. Born too soon: the global action report on preterm birth [Internet]. Genebra: WHO; 2012 [cited 23 may 2017]. Available at: http://www.who.int/ pmnch/media/news/2012/201204_borntoosoon-report.pdf

3. World Health Organization. WHO recommendations on antenatal care for a positive pregnancy experience [Internet]. Genebra: WHO; 2016 [cited 23 may 2017]. Available at: http://apps.who.int/iris/bitstre am/10665/250796/1/9789241549912-eng.pdf?ua=1

4. Sanches MTC, Costa R, Azevedo VMGO, Morsch DS, Lamy ZC, organizadores. Método Canguru no Brasil: 15 anos de política pública. São Paulo: Instituto de Saúde; 2015.

5. Ministério da Saúde (BR). Atenção humanizada ao recémnascido: Método Canguru: caderno do tutor. Brasília: MS; 2014.

6. Visscher $\mathrm{MO}$, Adam R, Brink S, Odio M. Newborn infant skin: physiology, development, and care. Clin Dermatol. 2015;33(3):271-80. https://doi.org/10.1016/j. clindermatol.2014.12.003

7. Santos SV, Costa R. Prevention of newborn skin lesions: knowledge of the nursing team. Texto Contexto Enferm 2015;24(3):731-9. https://doi.org/10.1590/0104-07072015 011230014

8. Lund C. Bathing and beyond: current bathing controversies for newborn infants. Adv Neonatal Care 2016;16(Suppl 5):13-20. https://doi.org/10.1097/ANC.0000000000000336

9. Cheever KH, Hinkle JL. Brunner \& Suddarth: tratado de enfermagem médico-cirúrgica. 13a ed. Vol. 1. Rio de Janeiro: Guanabara Koogan; 2015.

10. Santos SV, Costa R. Treatment of skin lesions in newborn children: meeting the needs of nursing staff. Rev Esc Enferm USP. 2014;48(6):985-92. https://doi.org/10.1590/S0080623420140000700004
11. Conselho Nacional de Saúde (BR). Resolução n. 466, de 12 de dezembro de 2012 [Internet]. Brasília; 2012 [cited 23 may 2017]. Available at: http://bvsms.saude.gov.br/bvs/ saudelegis/cns/2013/res0466_12_12_2012.html

12. Lund $\mathrm{CH}$. Medical adhesives in the NICU. Newborn Infant Nurs Rev. 2014;14(4):160-5. https://doi.org/10.1053/j. nainr.2014.10.001

13. Visscher $M$, Narendran $\mathrm{V}$. Neonatal infant skin: development, structureand function. Newborn Infant Nurs Rev. 2014;14(4):13541. https://doi.org/10.1053/j.nainr.2014.10.004

14. Nist MD, Rodgers EA, Ruth BM, Bertoni CB, Bartman T, Keller $L A$, et al. Skin rounds: a quality improvement approach to enhance skin care in the neonatal intensive care unit. Adv Neonatal Care. 2016;16(Suppl 5):33-41. https://doi. org/10.1097/ANC.0000000000000337

15. Cousins Y. Wound care considerations in neonates. Nurs Stand. 2014;28(46);61-70. https://doi.org/10.7748/ ns.28.46.61.e8402

16. Sathiyamurthy S, Banerjee J, Godambe SV. Antiseptic use in the neonatal intensive care unit - a dilemma in clinical practice: an evidence-based review. World J Clin Pediatr 2016;5(2):159-71. https://doi.org/10.5409/wjcp.v5.i2.159

17. Imbulana DI, Manley BJ, Dawson JA, Davis PG, Owen LS. Nasal injury in preterm infants receiving non-invasive respiratory support: a systematic review. Arch Dis Child Fetal Neonatal Ed. 2018;103:29-35. https://doi.org/10.1136/ archdischild-2017-313418

18. Biranjia-Hurdoyal SD, Pandamikum L. A study to investigate the prevalence of nappy rash among babies aged 0 to 36 months old in a tropical country. Austin J Dermatol. 2015;2(2):id1040.

19. Šikić PM, Maver U, Marčun VN, Mičetić-Turk D. Diagnosis and management of diaper dermatitis in infants with emphasis on skin microbiota in the diaper area. Int J Dermatol. 2018;57(3):265-75. https://doi.org/10.1111/ ijd.13748 
20. Faria TF, Kamada I. Lesões de pele em neonatos em cuidados intensivos neonatais. Enfermería Global. 2018;49:220-8. https://doi.org/10.6018/eglobal.17.1.273671

21. Johnson DE. Extremely preterm infant skin care: a transformation of practice aimed to prevent harm. Adv Neonatal Care. 2016;16(Suppl 5):26-32. https://doi. org/10.1097/ANC.0000000000000335

22. Yurdakök M. Phototherapy in the newborn: what's new? J Pediatr Neonat Individual Med. 2015;4(2):e040255. https:// doi.org/10.7363/040255
23. Abdelazeem KS, Soliman AA, Askar EAA. Efficacy of intensive phototherapy in management of neonatal hyperbilirubinemia in neonatal unit of Assiut university children hospital. J Neonatal Biol. 2017;6(3):1000266. https://doi.org/10.4172/2167-0897.1000266

24. Schardosim JM, Ruschel LM, Motta GCP, Cunha MLC. Cross-cultural adaptation and clinical validation of the Neonatal Skin Condition Score to Brazilian Portuguese. Rev Latino-Am Enfermagem. 2014;22(5):834-41. https://doi. org/10.1590/0104-1169.3456.2487 